\section{MALAI MONGKHON: A CASE OF POSTMODERN THAI THEATRE}

\section{Kittisak Kerdarunsuksri ${ }^{1}$}

\begin{abstract}
Modern stage drama was introduced into Thai theatre during the mid-1960s within the university circle and later spread to the commercial level. To make their productions more attractive and accessible to popular audiences, some theatre practitioners sought to experiment with adopting indigenous sources, either traditional stories or theatrical elements, which have been found in modern Thai theatre from time to time since the early 1970s. During the 1990s, several productions made use of traditional stories and elements to a greater degree due to many factors, such as the promotion of Thainess, the demand for original Thai plays, and the trend in Southeast Asian theatre. Most of these productions can thus be considered as postmodern Thai theatre since revisiting the past, disrupting the distinction of high and low art forms, and juxtaposing unmatched elements are clearly discernible. Makhampo'm's Malai Mongkhon, adapted from the myth of Phra Malai, was one of the works based on traditional Thai literature produced in this period. Not only was the myth used, but this production also made use
\end{abstract}

\footnotetext{
${ }^{1}$ Lecturer, Department of Thai Language for Communication, Faculty of Humanities, University of the Thai Chamber of Commerce, Thailand.
}

of traditional theatrical elements, both court and folk, in juxtaposition with modern techniques. This production can be regarded as a representative of postmodern Thai theatre in the 1990s.

\section{Introduction}

During the 1990 s, the adaptation of traditional Thai literary works into modern stage drama (lakho'n wethi samai mai) seemed to be a popular trend in the Thai theatrical circle both on commercial and non-commercial levels. ${ }^{2}$ Not only were the traditional stories adopted in these productions, but traditional theatrical elements, such as costume, set design, music, song, and dance style, were also juxtaposed with modern elements-which can be viewed as 'postmodern Thai theatre'. Even though the use of traditional elements in modern Thai theatre had existed since the 1970 s, for example, the productions of Kamron Gunatilaka ${ }^{3}$, such a retrieval of the past in 1990s Thai theatre seemed to agree with what happened in society. This paper therefore investigates the social context as well as factors in Thai theatre that have encouraged such a

\footnotetext{
${ }^{2}$ In fact, the first adaptation of traditional literature into modern stage drama was Witayakorn Chiengkul's Nai Aphaimani adapted from Suntho'n Phu's classical work, Phra Aphaimani. This play was staged in 1971 among a small circle of students and intellectuals.

${ }^{3}$ To communicate with grass-roots audiences, Kamron made use of a combination of Western techniques and traditional elements, such as folk songs, games, and dancing, in a series of his productions called Chonnabot (The Rural).
} 
theatrical movement. It then selects the Makhampo'm Theatre Group's production of Malai Mongkhon, adapted from the myth of Phra Malai, as a case study to explore and demonstrate the characteristics of postmodern Thai theatre.

\section{A Return to the Roots: Internal and External Factors}

Having borrowed stories from Western plays, Thai theatre practitioners began to think in terms of communication with public audiences as well as national cultural pride. The demand for an understanding of their own culture sprang from practitioners and audiences. ${ }^{4}$ Moreover, certain practitioners, such as those in the commercial theatre in particular, realized that plays with complicated or profound ideas and philosophies like those of the West could not attract Thai audiences who have long been satisfied with 'sanuk' or lighthearted stories and thus came to the theatre principally for entertainment. ${ }^{5}$ This

${ }^{4}$ In her preface to a collection of original Thai modern plays (1991), Ratsami Phaolu'angtho'ng, a prominent director of Troupe 28 , stated that a number of audiences demanded that the troupe produce original scripts so that the stories could express ideas and issues appropriate to the Thai social context rather than translating and adapting Western plays.

${ }^{5}$ Since sanuk has long been rooted in Thai culture, it has become a criterion for the success of theatre and other entertainment. In performance, the sense of sanuk lies in a story with a variety of 'flavours' or emotions, humour in particular. For more details about sanuk and its function in Thai culture see Klausner (1993: 290-292). encouraged the call for original Thai modern plays - which had been rare since the censorship in the aftermath of the events of 6 October 1976.

Nevertheless, in the demand for original scripts, theatre practitioners wished to have plays of as high a standard as Western drama in terms of literary value. Projects for playwriting have occasionally been initiated. By 1989, for example, Troupe 28 encouraged Thai writers to turn to producing scripts for play reading. ${ }^{6}$ And since 1993, Dass Entertainment, a leading theatre company, has organized playwriting competitions under the name of the 'Sodsai Award' in honour of Sodsai Pantoomkomol, a pioneer of modern Thai theatre. ${ }^{7}$ The promotion of Thai playwriting is thus an effort to create original works in order to communicate with audiences within the same social and cultural context.

A way to create new scripts was turning to existing sources, that is, literary

\footnotetext{
${ }^{6}$ The prominent writers joining this project include writers and literary critics such as Manop Thano'msi, Si Daoru'ang, Camnongsi Rutnin, Phailin Rungrat, and Chatcharin Chaiwat.

${ }^{7}$ In the Sodsai Award, the contest is limited to university-level students only. At the final stage, the contestants need to stage their productions.
} 
works - either traditional or modern. ${ }^{8}$ However, traditional literature tended to be more popular on the modern stage. Generally, these literary works were chosen from the Thai literary canon and were usually taught at school. Certain works, such as the tales of Phra Malai and the Ramakian, have been deeply embedded in Thai culture; some have often been reproduced on television, for example, Manora, Phra Aphaimani and Khun Chang Khun Phaen. The reconstruction of traditional literary works on the modern stage then shows, in one sense, the attempt of contemporary theatre practitioners to guarantee the literary authenticity and value of their own productions. At the same time, the employment of traditional texts, which seem to be ignored by contemporary audiences, is a way to revitalize literary heritage. This is a function of these dramatists. As Laurence Coupe (1997: 19) said, 'Wherever myth has been pronounced dead, artists have risen up to

${ }^{8}$ For example, the Art and Drama Club of Thammasat University in 1988 initiated the project Yip Wannakam Tham Lakho'n Wethi (Bringing Literature to Make Stage Drama) in which contemporary short stories and novels were transposed to the stage. Later in 1997, the Phra Can Siaw Troupe adapted a SEAWrite Award winning novel, Taling Sung Sung Nak (High Bank, Heavy Log) written by Nikhom Raiyawa, for solo performance. proclaim it alive'.?

The first transposition of traditional pieces into modern stage drama in the 1990s was in 1992 when Phatravadi Mejudhon, a legendary actress launched her open-air theatre with a production of Singhakraiphop, adapted from a poetic tale of the same title written by Suntho'n Phu. This production was later selected by the Office of the National Culture Commission to be presented on national and international stages, e.g. the $3^{\text {rd }}$ ASEAN Theatre Festival. After this production, theatre groups, whether commercial or non-commercial, and including the Phatravadi Theatre itself, began to use traditional literary works as a source of their repertoire. Twenty productions based on traditional literature were staged in this decade. Of these theatrical productions, fifteen works were produced during the period of $P i$ Ronnarong Watthanatham or the Years of Thai Cultural Preservation (1993-97; hereafter, YTCP); only two of them were created under the government project for promoting traditional liter-

\footnotetext{
${ }^{9}$ Although certain traditional literary pieces cannot strictly be referred to as myth in that they do not offer an explanation of how something comes into existence, they equate more closely with the Greek term mythos or "traditional story" - which lies at the origin of the word "myth". As myth, according to Scholes and Kellogg (1966: 12), is simply interpreted as a "traditional plot which can be transmitted", these traditional literary works can be viewed as myth. Scholes and Kellogg further argue that mythic qualities are displayed by legend, folktale, and oral epic poetry alike.
} 
ary study, Khrongkan Si San Wannakam (the Colour of Literature Project) which made use of performing arts as a medium to enhance literature teaching and make it more enjoyable. This project was a stage in promoting the transposition of traditional literature into modern drama. And it is no exaggeration to say that the YTCP was a channel for the boom in transposing traditional literature, since most productions based on traditional works were created in this official period. ${ }^{10}$ Even though most of these productions neither had connection with this project nor were given financial support by government agencies, the cultural campaign during the YTCP likely paved the way for theatre practitioners to turn back to their cultural roots more easily.

During the 1990s, the campaign for Thainess and Thai identity was promoted in almost every sector of society due to an awareness of the cultural crisis resulting from socio-economic development. ${ }^{11}$ Moreover, globalization be-

${ }^{10}$ See the list of productions adapted from traditional literature in the 1990s in a Ph.D. thesis (Kittisak Kerdarunsuksri, 2001: 261264).

"In the latter half of the twentieth century, the socio-economic developments of Thailand moved along the lines of Western capitalism. As a result, Thai people were overwhelmed by the rapid growth of society and economics to which most of them were unable to adapt and with which they were unable to cope. Over the past three decades, Thai society rapidly and dramatically changed in every aspect to the extent that traditional values, morals, and lifestyles were disrupted (Witayakorn Chiengkul, 1996: 171-179). came a matter of public debate, in which anxiety about the survival prospects of indigenous culture and questions about the authenticity of Thainess were posed. But what is really Thai in today's society seems to be somewhat elusive. Whenever the subject of Thainess has been discussed, cultural heritage, such as dance, music, literature, dress, games, sports, foods, and so on, has always been referred to as representatives of Thainess despite the fact that these 'things' are rather irrelevant in today's circumstances. In reality, people's lifestyles, particularly those in urban areas, are subject to the culture of globalization: they consume imported or 'un-Thai' commodities, for example, Japanese electrical appliances, American fast food, German cars, French perfumes, Western pop music, etc. Nevertheless, these people usually claim an admiration for Thainess and their desire to remain Thai. This circumstance reflects the co-existence of Thai and unThai elements in society within the current of globalization. It is an attempt by Thai people to reconcile the overwhelming inevitability of cultural globalization with the nervous desire to be Thai. For Kasian Tejapira (1996: 385-403), a Thai political scientist, this cultural phenomenon can be seen as 'postmodern Thainess'.

In his two articles studying Thai Buddhism and cults in relation to popular culture, Peter Jackson (1999a: 5-60 and 1999b: 245-320), a Thai studies scholar, demonstrates the co-existence of various premodern, modern, and postmodern cultural trends in 1990 s Thailand. He argues that the emergence of a diverse range of 'prosperity reli- 
gions', popular movements that emphasize the acquisition of wealth during the economic boom of the 1980s and 1990s, cannot simply be described as 'modernist religious expressions' in the sense of following a path of doctrinal rationalization in that the cults such as the worship of the spirit of King Chulalongkorn, devotion to the Chinese Bodhisattva Guan Yin (Thai, Kuan Im), and movements surrounding some monks reputed to possess magic power, indicate a proliferation of supernatural non-reason (Jackson, 1999a: 48-49). ${ }^{12}$ Such popular movements in 1990s Thailand, as he points out, emerged from a convergence of premodern and postmodern trends, together with an overshadowing of the modern. Both premodern and postmodern symbolic orders commonly see the world as being beyond human beings' rational capacity to fully comprehend and controlity. While for premodernism, events in the world are seen as being influenced by non-human and superhuman powers, the world is seen by postmodernism as hypercomplex, that is, beyond human analytical powers to fully analyse, predict, or control (Jackson, 1999b: 291). In many ways, the premodern animism of the prosperity religions constitutes them as already being postmodern. For him, Thai Buddhism in the 1990s has therefore become increasingly postmodern, characterized by a resurgence of supernatural beliefs and rituals and an efflorescence of religious expression at the margins of state control. This also indicates an example of a culturally hybrid

${ }^{12}$ In Buddhism, the Bodhisattva is a holy being who expects to become a Buddha in the future. postmodern phenomenon in Thai society, as Jackson (1999b: 290-291) suggests:

...(I)n Thailand the largely but not exclusively village-based residue of pre-capitalist, preindustrial culture can be called 'premodern', while the statebased project of national development involving centralized control over administration, culture, and the media represents a combination of policies and tendencies that is commonly associated with Thai 'modernity'. In contrast, the retreat of the state from directing cultural production, its replacement by the market, and the concomitant rise of the commodification of culture in the 1990 s can be seen as representing the incursion of the 'postmodern' into contemporary Thai life.

Illuminated by the works of Kasian and Jackson, the concept of postmodernism should be generalized to explain cultural phenomena in contemporary Thai society. That is to say, if Thailand in the 1990s has been experiencing postmodernity, it may be assumed that all culture produced during this period should by definition be fashioned under the same conditions; otherwise, which cultural phenomena can be explained by postmodern concepts'. Although theatre per se can be seen as a marginal cul- 
tural activity in today's society ${ }^{13}$, the effort to communicate with audiences in a wider sphere by transposing traditional literature into theatre mirrors the resurgence of theatre in keeping with the market of capitalism. Likewise, the coexistence of hybrid theatrical elements, i.e. traditional and modern or Thai and foreign, is commonly visible in these productions. For this reason, the theatrical productions based on the transposition of traditional literature can therefore be considered as "postmodern Thai theatre".

\section{Background of the Phra Malai Myth and Malai Mongkhon}

In 1996, the Makhampo'm Theatre Group (MKP) staged eighty-two performances of Malai Mongkhon across the country under the Project of the Campaign against AIDS and for Sexual Ethics among Teenage Group. ${ }^{14}$ The play was written and directed by Pradit Prasartthong, who was also one of the cast. The story dealt with teenagers' sexual behaviour which led to HIV infection.

Malai Mongkhon is based on an idea from the religious myth of Phra Malai, a Buddhist mahathera (great senior monk), who visits heaven and hell. The

${ }^{13}$ While theatre has gone from a dominant art form in early modern Europe to a relatively minor one in the postmodern Western world, it in turn is presented through other media, such as television, film, computer, etc. In Birringer's view, theatre is incapacitating in the postmodern world (1991: x-xi). ${ }^{14}$ This production was also staged in Australia for twenty performances. myth deals with Phra Malai, a compassionate monk, who induces people to make merit and stop committing sin in order to be reborn in the age of Bodhisattva Metteyya, the next Buddha. The myth begins with Phra Malai travelling to hell to bestow mercy on the suffering beings there. Upon his arrival, the inhabitants of hell ask him to urge their relatives in the human realm to make merit on their behalf. Phra Malai returns to the human world and does as he was asked. After the relatives perform the acts of merit, the inhabitants of hell are reborn in heaven. One day, a poor man presents lotuses to Phra Malai, which the monk then presents to the Culamani Cetiya, where the Lord Buddha's hair relic is enshrined, in heaven. There, he converse with the God Indra about what meritorious deeds the deities made in the past to earn the reward of being reborn in heaven. When he meets Metteyya, the Bodhisattva passes him a message to the people in the human world who wish to be born in his time - in which human beings will live in peace and prosperity. The message is about the ways to enable them to meet the Bodhisattva such as observing religious precepts and listening to the sermon of the entire Vessantara Jataka, all one thousand verses, in one day and one night. ${ }^{15}$ After Phra Malai returns to the human realm, he delivers Metteyya's message to people. The story ends with a reference to the man who

is The Vessantara Jataka is the story of the last past life of Lord Buddha before he was born as Prince Siddhattha who discovered the path to Enlightenment. The story deals with the significant practice of dana (distributing alms) of Prince Vessantara. 
offered Phra Malai the lotuses. After his death, he becomes a deity as a consequence of presenting the lotuses to Phra Malai.

It is believed that the story of Phra Malai has its origin in the Pali text, Maleyyadevattheravatthu, probably written in the twelfth century. ${ }^{16}$ In Thailand, there are a large number of Phra Malai manuscripts, both court and folk versions. The myth has long had a large influence on Thai life as the story has been deeply embedded in Thai society and culture through oral traditions, painting, sculpture, and manuscripts. For centuries, it has also played an important and colourful role in religious ceremonies, teaching, and even entertainment. What appears in the story reflects Thai beliefs and folk life. Offering alms, for example, is to dedicate the outcome of a meritorious deed to oneself or one's dead relatives so that the benefit will help them to be reborn in heaven, and the tradition of listening to the sermon of the Vessantara Jataka derives from the belief in the age of the Bodhisattva Metteyya ${ }^{17}$. The concepts of heaven and hell, and the Metteyya age

${ }^{16}$ It is still unclear as to the origin of Maleyyadevattheravatthu and its place of origin. Some scholars believe that this Pali text was written in Sri Lanka since there are fragments of Singhalese manuscripts in the British Museum. Some argue that the text was composed in South East Asia, possibly in Burma by a Burmese monk. (See Brereton, 1995: 25-45 and Supaporn Makchang, 1978: 217.)

17 The Buddhist concept of the Metteyya age can be compared to the Western Utopia, which is an ideal society. are teachings on the ideology of karma in that the principles of right and wrong, merit and demerit, as well as reward and punishment are tangibly portrayed.

One way that has transmitted the myth of Phra Malai in the Thai cultural context is the chanting of the story at funeral wakes, which is known as suat malai (the chanting of Malai). ${ }^{18}$ The suat malai, performed by laymen, takes place after the recitation of the Pali Abhidhamma (a philosophic aspect of the Buddhist teaching) by monks. Traditionally, the chanting of Phra Malai at funeral ceremonies is held every night, usually for seven nights. As the suat malai developed from the chanting of monks, this semi-religious performance also uses four singers with four monk's fans (talapat) as in religious chanting. Although the details of the suat malai performance seem to be unique to each locality, the main characteristics are similar. The structure of the suat malai can be divided into four parts: suat poet (opening chant), suat rai or suat banyai (narrating chant), suat saek ru'ang (story-inserted chant), and suat sang pret or suat pit (closing chant).

${ }^{18}$ The suat malai at funerals was traditionally performed by monks. In King Rama I's reign, however, the king prohibited the performance of suat malai by monks as they usually used bawdy humour to entertain the listeners, which was deemed unsuitable for clergymen (Surapone Virulrak, 2000: 62-63 and 105). Today, the suat malai is still found in every region. The chanting is known by various other names, including lam suat (singing-chanting), ram suat (dancing-chanting), suat kharu'hat (chanting of laymen), suat khi mao (chanting of drunken people), and so on. 
The suat malai begins with the suat poet in which the chanters recite the Pali Abhidhamma and describe the background of Phra Malai. Then, the chanters narrate the travels of Phra Malai in hell and heaven, which is subject to the chanters' improvisation, in the suat banyai. Late at night, they improvise on the chanting in the suat saek ru'ang, adding other stories taken from folktales and literary works in order to entertain the deceased's friends and relatives all night long. During the suat saek ru'ang, the chanters usually use acting and props to create a sense of fun. The semi-religious performance then shifts to pure entertainment-skit, slapstick, bawdy humour, and pun. In the final night of the funeral ceremony, the suat sang pret is performed at the end of the chanting to give the benefit of the meritorious act, i.e. the telling of the Phra Malai story, to the dead, which is regarded as a way to ensure a favourable rebirth.

In the process of building the plot of Malai Mongkhon, the actors would improvise situations involving AIDS problems. Pradit then adopted these improvised incidents to create the scenes and the overall picture of the production. Like a major theme in the Phra Malai myth, this play addressed the concept of karma by illustrating the consequences of sin. The script of Malai Mongkhon was divided into six scenes:

\section{Opening scene}

\section{Introducing Phra Malai.}

Scene 1 (Death)

Mala and Mali, two male and female teenagers, died of a mysterious disease. After their death, they met Phra Malai, and both of them asked him where they would be reborn. As they wished to be reborn in heaven, the monk taught them not to be concerned about heaven or hell. Instead, they should aim to reach nirvana. He then took the two teenagers on a visit to heaven and hell.

\section{Scene 2 (Heaven)}

Phra Malai showed them around heaven where the deities were dancing. The enjoyment in heaven reminded Mala of his pleasure from joining his school friend, So'nram, in raping Pamela at a party. When Mali complained that she had never experienced her heavenly happiness, the monk mentioned to her a kanlapapru'k tree (wish-fulfiling tree), which existed in the Metteyya age.

\section{Scene 3 (Wish-fulfiling tree)}

At her home, Mali could ask for money and everything she wanted from her father, except his attention. Her father had a new wife, and so her mother had left her. As Mali was terribly upset by the break-up of her parents' marriage, she phoned her boyfriend, Mala, to meet up at a pub. However, it happened that Mala could not come as he promised because he was asked by So'nram to speak up for him. While Mali was waiting for Mala, a rich man lured her to drink alcohol. As she thought of her father living with his minor 
wife, she decided to be that man's minor wife, which caused Mala sorrow. So'nram then enticed Mala to find his pleasure with prostitutes.

\section{Scene 4 (God Indra's Palace)}

The God Indra's Palace was compared to a go-go bar. Mala was fascinated by the beautiful prostitutes, who could be compared to goddesses. Phra Malai then unfolded the truth about the prostitutes with whom Mala had had relation. The first prostitute was a poor girl who was sold by her parents. The second one was Pamela whom So'nram and he had raped at the school party, and who therefore had left school and become a prostitute to feed her fatherless child, while the last one was Mali, his ex-girlfriend who was so captivated by material things that she had become a prostitute to be able to buy what she wanted.

\section{Scene 5 (Hell)}

Mala and Mali were suffering from AIDS, which could be compared to a hell-like state. They asked Phra Malai where their spirits were going. The monk told them to adhere to the observance of meritorious acts as well as to rely on the religious principles for salvation. Mala and Mali repented of what they had done; they also forgave one another. As a result, they could pay respect to the Culamani Cetiya, which implies that they managed to save themselves from suffering.

\section{Malai Mongkhon: An Illustra- tion of Postmodern Thai The- atre}

'Postmodernism' is not simply a continuation or consequence of modernism, but sometimes diverse attempts to break away from modernist forms. In this sense, it is not actually 'post' modernism but co-existent with it. The term was initially used to explain what happened in art and culture, and later spread outwards to the realm of political theory. In the postmodern world, there is no single, objective account of reality due to the fact that everyone experiences things differently. What can be seen as 'postmodern theatre' is thus undisturbed by a lack of consistency or continuity. ${ }^{19}$

In postmodern theatre, the boundaries of dramatic forms and performance styles are remarkably breached. In the production of Malai Mongkhon MKP employed a variety of theatrical techniques, such as dialogue, singing, chanting, and dancing, to create dramatic effects. While the modernist dramatists usually attempt to seek unity within each dramatic genre "by adhering consistently

\footnotetext{
${ }^{19}$ According to Steven Connor (1996: 108109), the dramatists whose works plausibly represent postmodern theatre are Bertolt Brecht, Harold Pinter, Samuel Beckett, Tom Stoppard, and so on. Particularly, Stoppard's Travesties is the quintessence as the intricately-designed collisions of worlds are illustrated.
} 
to the set of conventions associated with that mode' (Brockett, 1995: 585), it seems difficult to identify Malai Mongkhon with any modern dramatic genres. In turn, MKP sought to turn to traditional dramatic forms, such as likay (popular musical dance-drama) - where singing, speaking, and dancing were the main elements - to please Thai audiences' taste.

Rather than being a new create form, cultural production in the postmodern world emerges from previous cultural production. In other words, postmodernism is a culture of quotations'. Whereas the modernists try to destroy the past, the postmodernists realize that the past must be revisited, but with irony (Eco, 1992: 225-228). This revisiting of the past may appear in the form of overt references to or reinvention of other previous works, or non-linear time scheme of narrative. Postmodern drama may include the arbitrary logic of overlapping world-systems or structures. In reinventing the past in Malai Mongkhon, it is clear that it is not the 'real' past. Instead, the past is created by certain cultural myths and stereotypes, which Fredric Jameson (1991: 19-25 and 279-296) calls 'false realism' and Jean Baudrillard (1983:25) calls 'simulation'.

In the same way, time in the plot of Malai Mongkhon is non-linear since it alternately switches between the life before and after death of the main characters, Mala and Mali, using Phra Malai to connect the past and present. The use of traditional story illustrates the reinvention of the past to communicate with contemporary audiences. MKP man- aged to bring religious beliefs deeply rooted in Thai culture to a campaign against AIDS. However, symbols in the myth, i.e. ton kanlaprapru'k (wish-fulfilling tree), ton ngiw (a tree in hell used for punishment), and the God Indra's palace, were ironically reinterpreted.

The belief in making merit to be rewarded in the next life in the Phra Malai story is altered as it contradicts the Buddhist concept of anatta (soulless self). The troupe's view is that the belief instills wrong values in Thai people; particularly, it promotes the atta (self) and passion, which obstruct mankind from achieving spiritual enlightenment (Personal interview with Pradit Prasartthong, 9 March 1998). ${ }^{20}$ The concept of merit-making in the myth is, in fact, a kind of religious device so that people avoid committing sin and turn to the practice of meritorious acts. From the troupe's point of view, merit-making for a better life is viewed as an investment in accordance with the principle of capitalism, which tends to be a materialist matter rather than a spiritual or religious one. This shows the troupe's attempt to use the essence of Buddhism

${ }^{20}$ It is remarkable that a large number of Thai Buddhists rely on religion to bring their wealth and well-being rather than salvation. The recent quintessential phenomenon of Thai-Buddhist identity was the cults of Luang Pho' (Reverend Father) Khun Parisuttho and the Dhammakaya Temple, which resulted in marketised forms of religious expression-derogatorily called phuttha phanit (commercialised Buddhism or commerce in Buddhism). (See for example, Jackson, 1999b: 245-320.) 
for long-term social and human development.

Also, the concept of ton kanlapapru' $k$, the wish-fulfilling tree which exists in the Metteyya age, was reinterpreted to be a symbol of materialism. From this magic tree, people in the Metteyya age can gain whatever they need, which, in the troupe's view, contrasts with the Buddhist teaching of withdrawing from desires and passions. In the play, the kanlapapru' $k$ tree is depicted as parents who can offer their children only material things, i.e. Mali's father:

Phra Malai: You have found it [heaven]. Everywhere exist the so-called heaven and hell which people create themselves. You are bound to remember the feeling when you fulfilled all your desires as if you had found the magic kanlapapru'k tree in the Metteyya age.

Mali: Kanlapapru'k.

(Malai Mongkhon: scene 2)

and

Mali: The kanlapapru'k tree! I have got it at home. I can ask for everything I need.

- A chorus changes to Mali's father who is dressing to go to work. The kanlapapru'k tree appears. Mali comes to her father.

Father: I have to go to work now.

- Mali's father snaps his fingers. Two choruses stand behind Mali and enact gestures, such as brushing her teeth, washing her hair, dressing her, etc.

Mali: $\quad$ Father, I want to...

Father: I love you.

- Mali's father clicks his fingers again. Two choruses offer things to Mali.

(Malai Mongkhon: scene 3)

Mali's father gives her only things, whereas he has no time for her. Moreover, he breaks up with her mother for he has a minor wife. To seek affection, Mali therefore goes out to a bar where she expects to meet her boyfriend, Mala. But when Mala does not show up, Mali is tempted into having sex with a rich man, which finally sets her on the path of prostitution. In Mali's view, her customers are also her kanlapapru'k tree:

- Mala takes off the third's angel mask and sees Mali.

Mala: $\quad$ Mali! It is you.

Mali: Yes, it is Mali, your unruly ex-girlfriend. Come on! Hurry up! I have another customer waiting. And you have to pay me. My new kanlapapru'k tree, please bear in mind that I have always been paid a lot. The kanlapapru'k tree that can give me everything except love.

(Malai Mongkhon: scene 4)

The kanlapapru'k tree in this production is juxtaposed with ton ngiw, a tree with sharp thorns found in hell and used for punishing people who commit adultery. The kanlapapru'k and ngiw trees represent the consequences of spoiling 
children as it may lead them into wrong behavior, such as drug addiction and prostitution. This means that the kanlapapru' $k$ tree can turn into the ngiw tree if children are not brought up appropriately:

\section{Mali: Love that I have longed for, but never found. The kanlapapru' $k$ ? No, it is not. This is the ngiw tree, actu- ally.}

Chorus: The ngiw tree.

Mali: I was pushed into hell where the ngiw tree is waiting to impale the wicked. So you [Mala] must come with me. You are also a wicked person because you harmed women.

(Malai Mongkhon: scene 4)

In Malai Mongkhon, the palace where the God Indra resides is compared to sexual pleasure. As Pradit points out, 'nang fa (female angels) are created to sexually serve thewada (male angels). According to the Phra Malai myth, when people who accumulate a degree of merit are reborn in heaven, they gain a number of angels as their servants. The more meritorious acts people perform, the more angels they obtain. The nang $f a$ can be viewed as prostitutes in heaven.' (Ibid.) In the play, while the nang $f a$ symbolizes the prostitutes, the God Indra is portrayed as a pimp:

- Indra posts a label on each female angel's breast. The angels hold a pillar.
Indra: At that time, the God Indra has female angels as his attendants. very attractive.

These heavenly ladies are

$$
\text { (In English) }
$$

Lady and gentleman welcome to INDRA PARADISE! [sic]

- Indra turns on the music, I Love Trouble; the go-go dancers-angels dance.

Indra: $\mathrm{Hi}$, young man! Come on! Try my angels. Find out whether my angels are as good as the angels on earth or not!

- Mala enjoys making love with these angels.

- Phra Malai appears.

Phra Malai: Is this what you call 'heavenly pleasure'? You should think about what has happened. Is it a meritorious deed? Look at these angels. What do you think they are feeling? Are they happy or upset?

(Malai Mongkhon: scene 4)

Obviously, the plot structure of Malai Mongkhon is systematically based on that of the suat malai. Like the suat poet in the suat malai, the opening scene begins with the chorus reciting the short Pali Abhidhamma and introducing Phra Malai who, in the play, comes to save mankind from sin as 'the world is being burnt by people's lustful behaviour'. (Malai Mongkhon: opening scene) Four actors carrying monk's fans are used to represent the ritual of death. In scene 1, the spirits of the teenage characters, Mala and Mali, meet Phra Malai, the monk then takes them to heaven and hell 
so as to 'make them consider the place where their spirits should be reborn'. (Malai Mongkhon: scene 1) The description of heaven and hell in this play can be viewed as the suat banyai in which the chanters narrate what Phra Malai sees there. Having seen the deities' dancing, Mala, in scene 2, thinks of paradise on earth in which he helps his friend rape a beautiful girl, Pamela. In this sequence, the myth of MekkhalaRammasun ${ }^{21}$, which explains the natural phenomenon of lightning and thunder, is added to the plot in order to demonstrate teenagers' behaviour, which can lead to a risk of sexual harassment:

- Pamela walks up and down. She looks very pretty. So'nram tries to chat her up, but she ignores him.

Chorus:Pamela, Pamela, Pamela, Pamela. A star!

Mala: Pamela is a school star.

- The chorus plays as gods and goddesses. Pamela becomes Mekkhala, while So'nram is Rammasun.

${ }^{21}$ The myth is about Mekkhala, the Goddess of the ocean, and Rammasun, one of the God Vishnu's reincarnations. As Mekkhala, who possesses a splendid crystal, is playing and dancing with the God Arjuna and the angels in the sky, the giant Rammasun desires to obtain her crystal and thus chases her. To obstruct his pursuit, the Goddess tosses her glittery crystal so that a flash irritates the giant's eyes - which causes lightning. With his anger, Rammasun throws his axe at the Goddess - which entails thunder. This myth can also be found in King Rama I's Ramakian; it has become a popular dance piece in traditional performance.
Mala: Pamela!

Chorus: Mekkhala! The very beautiful goddess who swings a crystal in her hand.

Mali: So'nram!

Chorus: Rammasun! The giant whose weapon is an axe.

(The Choet Ching Melody)

At that moment, the beautiful Mekkhala

lures the giant Rammasun by tossing the crystal in her hand.

(The Mekkhala Melody)

Mekkhala, whose hand carries the crystal, is flying in the sky.

Rammasun throws his powerful axe at her; she then flies away and sneers at him.

Tut-tut, the evil lady! I will tear your legs until you die. Rammasun is gnashing his teeth, but Mekkhala is fearless.

- The chorus changes to a group of teenagers, while Pamela and So'nram turn back into their regular characters.

Mala: Oh, yes! This reminds me of that night. So'nram tried to chat Pamela up at the school's New Year party, but she rejected him.

Pamela: No way! People like you will have no chance to have sex with me. You, chicken!

So'nram: Let's see. Hey, guys!

- So'nram drinks up his whisky. He and his friends rape Pamela. He also asks Mala to join them.

(Malai Mongkhon: scene 2) 
The insertion of the MekkhalaRammasun myth appears to have the same structure of the suat saek ru'ang in the suat malai. However, while other folktales and stories are added to the chanting mainly because the chanters need to entertain the listeners, the Mekkhala-Rammasun myth in this production indicates the application of the myth to deliver a message in the play. The myth, as Pradit sees it, reflects the interrelationship between men and women. (Personal interview with Pradit Prasartthong, 9 March 1998.) Mekkhala's crystal symbolizes femininity, beauty, or enticement, whereas the giant's axe represents maleness or power. Mekkhala and Rammasun can be viewed as the need for superiority between men and women. Pamela's beauty and arrogance place her life in danger, particularly when she tries to show off her beauty amid the male teenagers at the party. As a result of being raped, she is forced to become a prostitute to earn her living. At the same time, the depiction of So'nram reflects the need to exercise power over inferiors. The myth is also juxtaposed with the inappropriate leisure activities of young teenagers in today's society, such as partying, clubbing, drinking, or whatever, which may result in sexual harassment. This clearly illustrates the employment of the myth to connect traditional beliefs and a current social problem, namely, sexual harassment among teenagers.

Malai Mongkhon ends with a description of AIDS patients' sufferings and advice on the way out of such suffering, namely, by observing religious principles. This part can be regarded as the suat sang pret in the chanting - usually dealing with the teaching of making merit for a better life or a good rebirth as well as giving the benefit of chanting to the dead. It is clear that this production adopted religious teachings to educate teenage audiences about sexual morals, which was believed to be a way to reduce the rate of AIDS infection in communities. ${ }^{22}$

Unlike the concept of modern drama, in which disparate elements were harmonized into a unified whole, MKP juxtaposed modern elements with traditional elements, as can be seen from stage design, dance style, music, song, and costume. Theatrical elements were employed regardless of the distinction between high and low art forms. For example, traditional elements were taken from both court and folk culture.

This production was deemed to be an adjustment of the folk ritual performance of the suat malai in that the structure of the chanting was adapted to combine with Western performing arts. Furthermore, the theatrical presentation employed some elements of the folk lakho'n chatri in which performers function as dancers and musicians alternately. Likewise, the performers in this production had to play several roles, including dancing, singing, and playing music; one performer was trained to play various musical instruments. Following the use of the theatrical form of lakho'n chatri, the

\footnotetext{
${ }^{22}$ In Pradit's view, the use of a cultural dimension helped to fostee understanding between society and AIDS patients.
} 
set was simply designed to enable the performers to move between the instruments and the acting area conveniently and rapidly. The band was positioned at both sides with a small platform upstage, whereas the audience sat in a U-shape surrounding the performance area similar to the Western concept of the thrust stage, in which the audience watches a performance from three sides. On the small round platform was a pillar, which represented the settings, such as the pillar in a go-go bar, the ngiw tree, and the kanlapapru'k tree. ${ }^{23}$

Besides modern acting, both traditional and Western dance movements were used in the performance. Nevertheless, traditional dance movements, choreographed by Pradit himself, were, to a certain degree, adapted to make the dance movements more interesting and impressive. (Personal interview with Pradit Prasartthong, 9 March 1998.) He choreographed the dancing of Mekkhala and Rammasun by borrowing from khon performance the idea of khu' $n$ loy, an acrobatic posture in which a dancer stands upon another dancer in a fighting scene. But he replaced this standing on another dancer by having Mekkhala and Rammasun sit and dance on each other's shoulder. While traditional dance movement was usually employed to depict heavenly pleasure, Western dance and movement were used to reflect worldly pleasure and hellish suffering since the movements were able

${ }^{23}$ The pillar was decorated with cloths, which could be unfolded to symbolize the kanlapapru'k tree. to portray clearer, more vivid images than traditional dance. For instance, the angels' dancing when Phra Malai took Mala and Mali to heaven was choreographed in traditional style, while the sufferings of the inhabitants of hell and the angels' dancing in the go-go bar were fashioned in Western movement.

In the same way, the performance made use of both traditional and Western music to accompany the dancing. While traditional music performed live by the cast was used to a greater degree, Western pop was employed in the scene of the go-go bar. Traditional melodies in this production were borrowed from those used in folk chanting, lakho'n chatri, and court dance-drama. The sathukan and $w a$ melodies from the phleng na phat repertoire were used in a shortened form in the opening scene to create an atmosphere of ritual-related sacredness, for the story dealt with Buddhist themes. ${ }^{24}$ The lyrics in the part of Mekkhla-Rammasun were borrowed from King Rama I's Ramakian and the manuscript chanted in Ratchaburi. To create other dramatic effects, such as violence in the rape scene, the cast created sound effects using the musical instruments. In addition, the recitation was adapted by using the idea from West-

\footnotetext{
${ }^{24}$ Phleng na phat is a category of non-lyric songs used when a character expresses certain actions and feelings. Generally, the sathukan is used to worship the Three Gems of Buddhism, i.e. the Buddha, the Dharma or Teachings, and the Sangha or Monks. The wa melody in traditional dance-drama is used as a sign that performance is about to start.
} 
ern technique, namely, the performers reciting in different tones, so as to build the atmosphere of the story.

As for costume design, the chorus basically wore beige leotards and black short tights with brown loose and see-through trousers. While Mala was in a white leotard and short back tights with loose black see-through trousers, the colour of Mali's costume was designed in an opposite way, that is, black leotard and white skirt. Obviously, the colour of the costumes implied the theme of the story. While the brown costume reflected a connection with Buddhism, i.e. monk's robe, goodness and badness or merit and demerit were shown in black and white. In order to suggest the characters, decorations, such as mask, headdress, robe, shawl, were added to the basic costumes.

\section{Conclusion}

Malai Mongkhon exemplifies the features of postmodern Thai theatre. The reinvention of the past in Malai Mongkhon was not merely a result of nostalgical, but also an attempt to use culture to communicate with the audience in the same society and to create theatrical creativity and identity. The mixture of traditional and modern elements also reflected the modification of Thai culture to fit into cultural globalization. This phenomenon is not found in Thai theatre alone. The retrieval of indigenous performance has been a current trend in South East Asian theatre. Ironically, this trend has been propelled by the influence of Western theatrical concepts and techniques, i.e. the idea of community theatre, Brechtian tech- niques and avant-garde theatre (Kittisak, 2001: 128-129).

Indeed, postmodernism is still an ongoing process. This paper does not wish to offer a definition of postmodern Thai theatre, nor does it attempt a comprehensive explication of postmodern theory. Rather, it seeks to explore the 'postmodern' features found in Malai Mongkhon in order to demonstrate a watershed in the development of Thai theatre in the 1990s.

\section{References}

Baudrillard, Jean. 1983. Simulations. New York: Semiotext (e).

Birringer, Johannes. 1991. Theatre, Theory, Postmodernism. Bloomington: Indiana University Press.

Brereton, Bonnie Pacala. 1995. Thai Tellings of Phra Malai, Texts and Rituals Concerning a Popular Buddhist Saint. Arizona: Arizona State University.

Brockett, Oscar G. 1995. History of the Theatre. Massachusetts: Allyn \& Bacon.

Coupe, Laurence. 1997. Myth. London: Routledge.

Eco, Umberto. 1992. Postmodernism, Irony, the Enjoyable. In Modernism/ Postmodernism, ed. by Peter Brooker, pp. 225-228. London: Longman.

Jackson, Peter A. 1999a. The Enchanting Spirit of Thai Capitalism, The Cult of Luang Phor Khoon and the Post-modernization of Thai Buddhism. South East Asia Research 7. 1: 5-60.

Jackson, Peter A. 1999b. Royal Spirits, Chinese Gods, and Magic Monks: Thailand's Boom-time Religions of Prosperity. South East Asia Research 7. 3: 245-320. 
Jameson, Fredric. 1991. Postmodernism, or the Cultural Logic of Late Capitalism. London: Verso.

Kasian Tejapira. 1996. The Postmodernization of Thainess. In Proceedings of the $6^{\text {th }}$ International Conference on Thai Studies, Theme II: Cultural Crisis and the Thai Capitalist Transformation. Chiangmai, Thailand. 14-17 October 1996.

Kittisak Kerdarunsuksri. 2001. The Transposition of Traditional Thai Literature into Modern Stage Drama: The Current Development of Thai Theatre. Unpublished Ph.D. thesis, School of Oriental and African Studies, University of London.

Klausner, William J. 1993. Reflections on Thai Culture. Bangkok: Amarin Printing.

Makhampo'm Theatre Group. 1996. Malai Mongkhon. Unpublished script and videotape.

Personal interview with Pradit Prasartthong. 9 March 1998.

Scholes, Robert and Robert Kellogg. 1966. The Nature of Narrative. London and New York: Oxford University Press.

Supaporn Makchang. 1978. Maleyyadevattheravatthu: Kan Truat Chamra lae Kan Su'ksa Choeng Wikhro' (Maleyyadevattheravatthu: An Edition and an Analytical Study). Unpublished MA Thesis, Chulalongkorn University.

Surapone Virulrak. 2000. Wiwatthanakan Nattayasin Thai nai Krung Rattanakosin pho' so' 2325 2477 (The Evolution of Thai Theatre in Bangkok during 1782-1934). Bangkok: Chulalongkorn University Press.

Troupe 28. 1991. Ha Bot Lakho'n Wethi Thai (Five Thai Stage Plays). Bangkok: Samaphan.
Witayakorn Chiengkul. 1996. Kan Plianplaeng thang Watthanatham nai Ro'p Ha Sip Pi (The Cultural Changes during the Past Fifty Years) Sinlapawatthanatham 17. 8: 171-179. 